\title{
Penyesuaian Diri, Dukungan Sosial, dan Gaya Belajar Visual terhadap Stres Akademik Siswa di Masa Pandemi
}

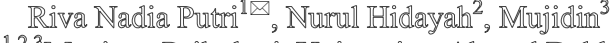 \\ 1,2,3 Magister P silkologi, Universitas Alhmad. Dalhlan \\ 1rivanadiaputri23@gmai1.com,2nuru1.hidayah@psy.uad.ac.id, 3natabaya74@yahoo.com
}

\begin{abstract}
This study aims to test empirically the effect of self adjustment, social support, visual learning style on academic stress in seventh grade students of SMP Negeri X Yogyakarta. This research method is a quantitative method with a Likert scale model as a data collection tool. The subjects of this study were seventh grade students of SMP X Yogyakarta. The sampling technique was carried out by cluster random sampling technique. Data analysis of this research is multiple regression analysis technique with the help of SPSS 21 program. The results of data analysis showed: (1) there was a very significant influence between self-adjustment, social support, visual learning style on academic stress as indicated by $F$ reg $=107.076$ with $p$ value $=0.000(p<0.01)$. (2) there is an effect of adjustment to academic stress which is indicated by the value of $t=-13,349$ with a value of $p=0.000(p<0.01)$. (3) there is no significant effect between social support and academic stress as indicated by the value of $t=-1.726$ with a value of $p=0.086(p>0.01)$. (4) There is no significant effect between visual learning style and academic stress which can be seen from the value of $t=1.944$ with a value of $p=0.054(p>0.01)$. The conclusion of this research is that there is an effect of self adjustment, social support, visual learning style on academic stress.
\end{abstract}

$\mathbb{K}$ eywwords: Self Adjusment, Social Support, Visual Learning, Style, Academic Stres.

\begin{abstract}
Abstrak
Penelitian ini bertujuan untuk menguji secara empiris pengaruh penyesuaian diri, dukungan sosial, gaya belajar visual terhadap stress akademik pada siswa kelas VII SMP X Yogyakarta. Metode penelitian ini adalah metode kuantitatif dengan skala model likert sebagai alat pengumpulan data. Sampel penelitian ini adalah siswa kelas VII SMP X Yogyakarta.Teknik pengambilan sampel dilakukan dengan teknik cluster random sampling. Analisis data penelitian ini adalah teknik analisis regresi berganda dengan bantuan program SPSS 21. Hasil analisis data menunjukan : (1) terdapat pengaruh yang sangat signifikan antara penyesuaian diri, dukungan sosial, gaya belajar visual terhadap stres akademik yang ditunjukan dari $F$ reg $=$ 107,076 dengan nilai $p=0,000(p<0,01)$. (2) terdapat pengaruh penyesuaian diri terhadap stres akademik yang ditunjukan dari nilai $t=-13,349$ dengan nilai $p=0,000(\mathrm{p}<0,01)$. (3) tidak terdapat pengaruh yang signifikan antara dukungan sosial dengan stres akademik yang ditunjukan dengan nilai $t=-1,726$ dengan nilai $p=0,086(p>0,01)$. (4) Tidak terdapat pengaruh yang signifikan antara gaya belajar visual dengan stres akademik yang dapat dilihat dari nilai $t=1,944$ dengan nilai $p=0,054$ $(p>0,01)$. Kesimpulan hasil penelitian ini adalah terdapat pengaruh penyesuaian diri, dukungan sosial, gaya belajar visual terhadap stress akademik.
\end{abstract}

Kata Irumei: Dukungan Sosial, Gaya, Belajar Visual, Penyesuaian Diri, Akademik Stres.

(C) 2021 PSY165 Journal

\section{Pendahuluan}

Setiap individu akan mengalami masalah dalam kehidupan mereka. Masalah yang dinilai melebihi kemampuan seseorang dalam menyelesaikanya maka dapat menimbulkan stress. Stres dapat terjadi dimana saja termaksud lingkungan sekolah. stres dilingkungan sekolah terjadi karena beberapa alasan seperti banyaknya tuntutan akademik namun tidak memiliki kemampuan yang cukup untuk memahami permasalahannya serta tidak dapat melakukan penyesuaian diri dengan baik [1]. Remaja di yogyakarta sebanyak $77.8 \%$ mengalami stres akademik yang disebabkan oleh tuntugas akademik yang berlebihan dimasa pandemi, seperti tugas yang terlalu banyak, ujian sekolah dan lingkungan sosial [2]. Perubahan tuntutan belajar dari masa sebelumnya juga menyebabkan munculnya stress akademik.
Kondisi ini disebabkan oleh tuntutan yang tinggi terhadap siswa untuk lebih berpretasi. Tuntutan yang tinggi itu seringkali menjadi pemicu stress pada perserta didik, khususnya pada siswa yang tidak memiliki kesiapan dan kedisiplinan dalam belajar [3]. Perubahan belajar yang terjadi seperti perubahan tingakatan akademik dari SD ke SMP. Siswa-siswa kelas VII yang mengalami masa transisi dari SD ke SMP mengalami "top-dog phenomenon" yang merupakan keadaan bergerak dari posisi teratas (kondisi siswa menjadi paling tua, paling besar, dan paling berkuasa di sekolah) ke posisi terendah (siswa menjadi paling muda, paling kecil dan paling lemah) [4]. Tahun pertama di masa SMP dapat menyulitkan banyak siswa. Hal ini akan menjadi tantangan bagi siswa, jika mereka merasakan tekanan dalam proses pembelajaran dan dapat dikelola dengan baik maka

Diterima: 05-11-2021 | Revisi: 15-11-2021 | Diterbitkan: 31-12-2021 | DOI: 10.35134/jpsy165.v14i4.136 
hasilnya tentu akan baik. Sebaliknya, jika siswa tidak dapat melaui tantangan ini dengan baik maka akan berdampak negatif bagi hasil belajar mereka.

Stres akademik yang dirasakan siswa SMP kelas VII di Yogyakarta antara lain adalah merasa tertekan dengan tugas yang tidak henti diberikan setiap hari. Mereka merasa cemas ketika diberikan tugas, sulit tidur dimalam hari sehingga tertidur dipagi hari, serta sulit berkonsentrasi selama pembelajaran online maupun dalam mengerjakan tugas. Mereka tidak siap dengan bentuk tugas maupun jumlah dari tugas yang ada. Pada situasi biasanya siswa hanya belajar di sekolah dan mendapatkan beberapa tugas untuk beberapa mata pelajaran saja, sedangkan ketika masa pandemi setiap mata pelajaran ada tugasnya dan itu berlangsung setiap hari serta harus dikumpulkan pada waktu yang sudah ditentukan. Hal ini membuat mereka berpacu dengan waktu dan pada akhirnya siswa merasa lelah memilih tidak mengumpulkan tugas. Ada juga yang mengeluhkan ketidakmampuan mereka dalam menyerap pelajaran ketika hanya dengan membaca materi-materi yang diberikan saja, mereka terbiasa mendengarkan guru menerangkan disekolah, sehingga mereka sulit memahami mata pelajaran yang diberikan dan akhirnya mereka melewatkan tugas yang diberikan guru. Mereka mengatakan bahwa tidak dapat belajar hanya dengan membaca saja, mereka tidak mengerti suatu materi ketika tidak dicontohkan atau dipraktekan langsung oleh guru yang bersangkutan.

Hasil wawancara peneliti dengan guru bimbingan konseling SMP 8 Yogyakarta menemukan data bahwa kelas VII dapat dikatakan paling mengalami kesulitan dalam beradaptasi dengan situasi pandemi ini. Kelas VII adalah siswa baru yang sebelumnya berasal dari jenjang pndidikan sekolah dasar. Mereka mendaftarkan diri di SMP 8 Yogyakarta dengan berbagai bentuk proses pendaftaran. Ada yang mendaftar karena mengikuti ujian bersama, sehingga dapat dikatakan mereka lulus karena nilai dan prestasi akademik sehingga mudah menyesuaikan diri dengan sekolah ini sebagai salah satu sekolah favorit di Yogyakarta. Ada beberapa siswa yang diterima di sekolah ini melalui jalur zonasi, sehingga jika jarak rumah mereka dekat dengan sekolah maka mereka dapat diterima tanpa melihat nilai dan prestasi akademik. Anak-anak yang diterima melalui jalur kedua inilah yang mengalami kesulitan beradapasi dengan sekolah dan sistem pembelajaran dirumah ini. Mereka yang sebelumnya belajar dibangku sekolah dasar tiba-tiba harus dihadapkan dengan pembalajaran secara daring tanpa ada tuntutan secara langsung lalu tiba-tiba diberikan tuntunan dan tugas-tugas sekolah yang sebelumnya pernah mereka hadapi secara langsung dibangku sekolah menengah pertama.

Berdasarkan data-data dan fenomena yang telah diuraikan diatas maka dapat dikatakan bahwa siswa kelas VII yang diwawancarai mengalami stress akademik. Hal ini dilihat dari beberapa indikator stress yang muncul pada siswa seperti merasa cemas ketika diberi tugas, sulit tidur dimalam hari dan kesulitan dalam berkonsentrasi selama pembelajaran maupun dalam mengerjakan tugas. Indikator gejala stres akademik emosional ditandai dengan timbulnya rasa cemas, indikator fisik yang dialami adalah sulit tidur dimalam hari sertai indikator kognitif ditandai dengan hilangnya konsentrasi pada saat belajar [5].

Pada dasarnya faktor penyebab dari stress akademik seperti yang sudah diuraikan sebelumnya merupakan hal yang normal terjadi pada seorang pelajar karena stress akademik merupakan bagian dari proses perkembangan diri seperti menyesuaikan diri dengan lingkungan sosial yang baru, penerimaan tanggung jawab dan peran baru sebagai seorang pelajar, memiliki beban belajar dan konsep pendidikan yang berbeda dengan tingkatan sekolah yang sebelumnya sehingga juga akan menambah beban belajar yang baru, belajar dalam mengatur keuangan, proses dalam manajemen waktu, harapan dan tantangan terhadap pencapaian akdemik, perubahan gaya hidup dari masa sekolah yang sebelumnya serta juga perkembangan konsep dirinya [6].

Berbagai perubahan yang di alami oleh siswa kemudian diikuti dengan banyaknya tuntutan yang mereka dapatkan sehingga menyebabkan munculnya beragam permasalahan seperti stress. Untuk menghadapi stress, diperlukan kemampuan penyesuaian diri. Penyesuaian diri merupakan suatu modal yang sangat penting untuk merespon tuntutantuntutan yang berasal dari dalam maupun dari luar individu. Siswa pada tahun pertama yang tidak berhasil menyesuaikan diri dengan lingkungan baru dapat mengalami berbagai masalah, termasuk masalah dalam membina hubungan dengan orang lain. Kegagalan siswa untuk mengatasi permasalahan dan melakukan penyesuaian terhadap kejadian-kejadian yang menekan tersebut akan memicu timbulnya depresi dan berbagai emosi negatif lainnya seperti merasa dirinya tidak berharga, munculnya perasaan sedih, marah atau pesimis, ditambah dengan tuntutan akademik yang lebih tinggi dibandingkan pada tingkat pendidikan sebelumnya. Situasi penuh tekanan seperti stress akademik juga akan berpotensi membuat siswa merasa minder atau menarik diri dari lingkungan sosial sekalipun secara virtual, cemas berlebihan sehingga sering marah-marah, dan sulit sekali berkonsentrasi serta memahami pelajaran selama belajar dari rumah. Kondisi krisis yang memicu stres pada siswa berpengaruh signifikan terhadap kesiapan belajar siswa dan juga performa akademis [7].

Selain penyesusian diri sebagai faktor internal, terdapat juga faktor ekstrenal yang dapat mempengaruhi stress akademik siswa yaitu berupa dukungan sosial. Dukungan sosial adalah bentuk kenyamanan, kepedulian, dukungan dan bantuan yang diberkan seseorang atau kelompok kepada orang lain 
[8]. Dukungan ini dapat berasal dari berbagai sumber seperti orang-orang yang disayang, keluarga, teman, organisasi maupun sebuah organisasi atau kelompok tertentu. Orang-orang yang mendapatkan dukungan sosial akan memiliki kepercayaan bahwa diri nya adalah bagian dari lingkungan tersebut.

Faktor lain yang menjadi permasalahan belajar dari para siswa adalah karakteristik belajar yang dimiliki oleh setiap peserta didik yang berkaitan dengan proses menyerap, mengolah, dan menyampaikan informasi (pesan) yaitu gaya belajar peserta didik. Gaya belajar adalah cara manusia mulai berkonsentrasi, menyerap, memproses, dan menampung informasi yang baru dan sulit [9]. Pada masa new normal, pembelajaran dilakukan dengan sistem virtual atau online. Pembelajaran virtual membuat membuat adanya perubahan gaya belajar pada siswa. Pada masa pandemi, gaya belajar yang sering digunakan siswa adalah gaya belajar visual [10]. Gaya belajar visual memfokuskan pengolahan informasi melalui gambar atau visualisasi. Sesuai dengan kondisi saat ini siswa belajar melalui media visual yaitu whatsapps, zoom, video tutorial dan gambar-gambar yang diberikan oleh guru. Perubahan gaya belajar inilah yang menjadi penyebab gaya belajar visual mulai banyak digunakan oleh siswa karena keterpaksaan kondisi dan situasi pandemi.

Stres akademik adalah jenis stress yang disebabkan karena peningkatan beban kerja kelas, status yang lebih rendah dari yangdiperkirakan, harapan kelulusan, dan ketidaksepakatan yang parah dengan mentor. Stres akademik memicu persepsi individu tentang frustrasi akademik, konflik akademik, tekanan akademis, dan kecemasan akademik yang merupakan komponen stres akademik [11]. Stres akademik adalah sebuah respon yang muncul ketika terjadinya ketegangan atau tekanan yang disebabkan oleh tuntutan akademik yang sudah menjadi kewajiban dan harus dikerjakan oleh seseorang [12]. Terdapat 4 komponen stres akademik yang terdiri dari tekanan terhadap kinerja siswa, persepsi terhafap beban tugas dan ujian, persepsi diri, dan pembatasan waktu [13].

Penyesuaian diri adalah sebagai usaha manusia untuk mencapai sebuah keharmonisan pada diri sendiri dan lingkungannya, sehingga emosi dan perasaan negatif seperti rasa permusuhan, iri hati, dengki, dan prasangka sebagai respon pribadi yang tidak sesuai dan kurang efisien dapat diminimalisir bahkan dihapuskan [14]. Selain itu penyesuaian diri adalah sebuah proses yang mencakup respon-respon mental dan tingkah laku individu untuk mampu mengatasi kebutuhan, ketegangan, konflik, dan rasa frustasi, dimana usaha tersebut bertujuan untuk memperoleh keselarasan dan keharmonian antara tuntutan dalam diri dan tuntutan lingkungan [15]. Penyesuaian diri memiliki enam aspek antara lain kontrol terhdap emosi yang berlebihan, mekanisme pertahanan diri, frustasi personal yang minimal, pertimbangan rasional dan kemampuan mengarahkan diri, kemampuan belajar dan memanfaatkan pengalaman, sikap realistis dan objektif [15].

Dukungan sosial adalah sebuah bentuk kenyamanan, kepedulian, dukungan dan bantuan yang diberikan oleh seseorang kepada orang lain maupun sebuah kelompok [8]. Dukungan sosial juga merupakan sebuah informasi dan umpan balik dari orang lain yang menunjukan bahwa seseorang dicintai dan diperhatikan, dihargai, dihormati serta dilibatkan dalam komunikasi yang ada hubungan timbal baliknya [16]. Dukungan sosial merupakan salah satu fungsi dari ikatan sosial, dan ikatan-ikatan sosial tersebut menggambarkan tingkat kualitas umum dari hubungan interpersonal. Dukungan sosial memiliki dimensi yang terdiri dari attachment, social integration, reasure of worth, reliable aliance, guidance dan opportunity for nurturance [17].

Gaya belajar visual merupakan gaya belajar dengan cara melihat seperti memperhatikan tulisan dipapan tulis, membaca catatan dan buku, melihat grafik dan gambar serta bentuk visual lainnya [18]. Gaya belajar visual merupakan proses yang bersandar pada indera penglihatan ketika menyerap informasi. Pelajar dengan gaya belajar visual tertarik kepada pemandangan yang akrab, dan mengingatkan tandatanda visual seperti gerak, warna, bentuk, dan ukuran. Tipe belajar ini memiliki kecenderungan bawaan untuk melihat sesuatu yang kemudian tangannya menunjuk apa yang dilihat [19]. Terdapat beberapa ciri-ciri orang dengan gaya belajar visual : teratur, memperhatikan segala sesuatu, menjaga penampilan, mengingat dengan gambar, lebih suka membaca daripada dibacakan, membutuhkan gambaran dan tujuan menyeluruh [20].

Berdasarakan fenomena diatas stress akademik menarik untuk diteliti karena membahas mengenai reaksi individu ketika tidak mampu dalam menyelesaikan suatu tantangan dalam hidupnya yang ditandai dengan gejala-gejela yang dapat diamati. Penelitian ini memiliki dua hipotesis yaitu hipotesis mayor yaitu terdapat pengaruh penyesuaian diri, dukungan sosial, gaya belajar visual terhadap stres akademik siswa kelas VII SMP X Yogyakarta. Hipotesis selanjutnya adalah hipotesis minor uang terdiri dari: (1) terdapat pengaruh penyesuaian diri terhadap stres akademik; (2) terdapat pengaruh dukungan sosial terhadap stres akademik; (3) terdapat pengaruh gaya belajar visual terhadap stres akademik.

\section{Metodologi Penelitian}

Penelitian ini menggunakan metode penelitian kuantitatif. Populasi dari penelitian ini adalah seluruh siswa kelas VII SMP X Yogyakarta. Sampel penelitian ini adalah siswa kelas VII SMP X Yogyakarta sebanyak 167 siswa yang diambil berdasarkan teknik sampling cluster random sampling. 
Metode pengumpulan data yang digunakan peneliti adalah dengan menggunakan skala psikologi yang berjenis likert. Variabel stres akademik diukur menggunakan skala adaptasi dari Bedewy dan Gabriel [13] dengan mengguanakn komponen-komponen stres akademik. Variabel penyesuaian diri diukur dengan menggunakan skala adaptasi dari aspek-aspek yang dikemukakan oleh Schneider [15] yang mengacu pada aspek-aspek yang dikemukakan oleh Schneider. Variabel dukungan sosial diukur dengan menggunakan adaptasi skala yang mengacu pada empat aspek-aspek dukungan sosial yang dikemukakan oleh Cuttrona dan Russell [17]. Variabel gaya belajar visual diukur dengan menggunakan skala adaptasi yang mengacu pada tiga krakteristik gaya belajar visual yang dikemukakan oleh Deporter dan Hernacki [20].

\section{Hasil dan Pembahasan}

Penelitian ini menggunakan analisis data yaitu analisis regresi. Pada analisis regresi terdapat beberapa uji asumsi yang harus dipenuhi sebelum melakukan uji hipotesis. Uji asumsi yang harus dipenuhi dalam analisis regresi sederhana terdiri dariuji normalitas, uji linearitas, dan uji multikolinearitas. Hasil uji normalitas dari ke empat variabel yang sudah dianalisis adalah sebagai berikut : diketahui bahwa pada sebaran data variabel stress akademik memiliki $\mathrm{p}$ $=0,282(\mathrm{p}>0,05)$, sehingga variabel stress akademik memiliki sebaran normal atau setiap data terdistribusi normal. Sebaran data variabel penyesuaian diri memiliki $\mathrm{p}=0,303(\mathrm{p}>0,05)$, sehingga variabel penyesuaian diri memiliki sebaran normal atau setiap data terdistribusi normal. Sebaran data variabel dukungan sosial memiliki $\mathrm{p}=0,053$ ( $\mathrm{p}>0,05)$, sehingga variabel dukungan sosial memiliki sebaran normal atau setiap data terdistribusi normal. Sebaran data variabel gaya belajar visual memiliki $\mathrm{p}=0,096(\mathrm{p}$ $>0,05)$, sehingga variabel gaya belajar visual memiliki sebaran nomal atau setiap data terdistribusi normal. Hasil uji normalitas menunjukkan bahwa keempat variabel memiliki distribusi skor yang normal sehingga dapat digeneralisasikan dalam populasi dan dapat dilakukan uji asumsi berikutnya.

Hasil uji linieritas antara variabel penyesuaian diri dengan stress akademik menunjukkan nilai $p$ (linearity) sebesar $0,000(\mathrm{p}<0,05)$ dengan nilai $\mathrm{p}$ (deviation from linierity) sebesar 0,02 ( $<<0,05$ ). Hasil uji linieritas mengindikasikan bahwa hubungan antara kedua variabel tersebut yaitu penyesuaian diri dengan stress akademik adalah linier. Variabel dukungan sosial dengan stress akademik menunjukkan nilai $\mathrm{p}$ (linierity) sebesar $0,000(\mathrm{p}<0,05)$ dan nilai $\mathrm{p}$ (deviation from linearity) sebesar 0,225 ( $\mathrm{p}>0,05$ ). Hasil uji linieritas mengindikasikan bahwa hubungan antara kedua variabel tersebut yaitu dukungan sosial dengan stress akademik adalah linear. Variabel gaya belajar visual dengan stress akademik menunjukkan nilai $\mathrm{p}$ (linierity) sebesar $0,000(\mathrm{p}<0,05)$ dan nilai $\mathrm{p}$ (deviation from linierity) sebesar 0,010 ( $\mathrm{p}<0,05$ ). Hasil uji linieritas mengindikasi bahwa hubungan antara kedua variabel tersebut yaitu gaya belajar visual dengan stres akademik adalah linier.

Uji Multikolinearitas dilakukan kepada ketiga variabel bebas terhadap variabel tergantung dalam penelitian ini dengan hasil pada penyesuaian diri, dukungan sosial, dan gaya belajar visual diperoleh nilai Tolerance dari masing-masing variabel sebesar 0,569 , $0,665,0,734$, sementara pada nilai VIF diperoleh sebesar 1,757, 1,503, 1,363, dengan demikian dapat dikatakan bahwa pada setiap variabel independen tidak terjadi multikolinieritas.

Berdasarkan hasil analisis regresi berganda untuk hipotesis mayor diperoleh nilai $\mathrm{F}$ pada penyesuaian diri, dukungan sosial, gaya belajar visual terhadap stress akademik sebesar 107,076 dengan taraf signifikansi $0,000(\mathrm{p}<0,01)$. Artinya ada secara bersama-sama terdapat pengaruh yang sangat signifikan dari penyesuaian diri, dukungan sosial, dan gaya belajar visual terhadap stress akademik dengan sumbangan efektif (R Square) yang dihasilkan sebesar $66,3 \%$ yang disajikan pada Tabel 1 .

Table 1. Analisis Regresi Berganda

\begin{tabular}{llllll}
\hline Variabel & $\mathrm{F}$ & $\mathrm{R}$ & $\begin{array}{l}R \\
\text { Square }\end{array}$ & Sig. & Keterangan \\
\hline Penyesuaian & 107,0 & 0,814 & 0,663 & 0,00 & Sangat \\
diri, & 76 & & & 0 & signifikan \\
Dukungan & & & & & \\
sosial, Gaya & & & & & \\
belajar & & & & & \\
visual & & & & & \\
terhadap & & & & & \\
stres & & & & & \\
akademik & & & & & \\
\hline
\end{tabular}

Hipotesis mayor pada penelitian ini adalah terdapat pengaruh penyesuaian diri, dukungan sosial, dan gaya belajar visual terhadap stress akademik pada siswa SMP X Yogyakarta. Analisis regresi memperoleh hasil bahwa hipotesis diterima yang menunjukkan adanya pengaruh yang sangat signifikan antara penyesuaian diri, dukungan sosial, dan gaya belajar visual dengan stress akademik pada siswa SMP X Yogyakarta. Hal ini dibuktikan dengan nilai signifikasi p sebesar 0,000 (p<0,050).

Hasil penelitian ini didukung oleh beberapa penelitian lain yang menyatakan bahwa penyesuaian diri memiliki pengaruh negatif terhadap stress akademik [21], dukungan sosial berpengaruh dalam menurunkan tingkat stres akademik siswa selama masa pandemi [22], serta gaya belajar sangat mempengaruhi stress akademik siswa ditahun pertama sekolah [23].

Table 2. Analisis Regresi Partial terhadap Stress Akademik

\begin{tabular}{lrll}
\hline Variabel & \multicolumn{1}{l}{ T } & Sig $(\mathrm{P})$ & Keterangan \\
\hline Penyesuaian diri & $-13,349$ & 0,000 & Sangat signifikan \\
Dukungan sosial & $-1,726$ & 0,086 & Tidak Signifikan \\
Gaya belajar visual & 1,944 & 0,054 & Tidak Signifikan \\
\hline
\end{tabular}


Tabel 2 adalah hasil analisis korelasi partial pada penyesuaian diri dengan stress akademik diperoleh nilai t sebesar -13,349 dengan taraf signifikansi 0,000. Selanjutnya, hasil analisis korelasi partial pada dukungan sosial dengan stress akademik diperoleh nilai t sebesar -1,726 dengan taraf signifikansi 0,086. kemudian, hasil analisis korelasi partial pada gaya belajar visual dengan stress akademik diperoleh nilai zero-order sebesar 1,944 dengan taraf signifikansi 0,054 . Hal tersebut menunjukkan bahwa secara partial penyesuaian diri berpengaruh negatif yang sangat signifikan terhadap stres akademik, dukungan sosial dan gaya belajar visual tidak berpengaruh signifikan terhadap stres akademik.

Hipotesis minor pertama pada penelitian ini adalah terdapat pengaruh penyesuaian diri terhadap stres akademik pada siswa kelas VII SMP X Yogyakarta. Berdasarkan analisa data yang dilakukan peneliti diketahui bahwa penyesuaian diri secara sangat signifikan berpengaruh terhadap stres akademik. Hasil analisis regresi menunjukan bahwa penyesuaian diri berpengaruh negatif terhadap stress akademik yang berarti semakin tinggi penyesuaian diri yang dimiliki siswa maka stress akademik pada siswa siswa SMP kelas VII semakin rendah dan sebaliknya. Penyesuaian diri mememiliki sumbangan yang lebih tinggi sebesar $64,9 \%$.

Penyesuaian diri adalah sebuah proses kehidupan seseroang untuk mengatasi kebutuhan, ketegangan, konflik, dan rasa frustasi, dimana usaha tersebut bertujuan untuk memperoleh keselarasan dan keharmonian antara tuntutan dalam diri dan tuntutan lingkungan. Penyesuaian diri merupakan salah satu faktor penting yang mempengaruhi stres akademik, penyesuaian diri dengan memiliki hubungan yang negatif dengan stres akademik [24]. Penyesuaian diri memiliki peran yang negatif terhadap stress akademik, hal tersebut menunjukkan bahwa semakin tinggi kemampuan penyesuaian diri seseorang maka semakin rendah tingkat stress akademik. Individu yang memiliki kemampuan yang baik dalam menyesuaikan diri terhadap tuntutan yang muncul di awal proses pembelajaran, maka akan mengurangi tingkat stres selama belajar. Sebaliknya jika seseorang ditahun ajaran pertama tidak dapat menyesuaikan diri dengan baik maka ia akan mudah mengalami stres akademik [25].

Hipotesis minor kedua pada penelitian ini adalah tidak terdapat pengaruh dukungan sosial terhadap stres akademik pada siswa kelas VII SMP X Yogyakarta. Dukungan sosial mememiliki sumbangan yang efektif sebesar 5\%. Pada hipotesis kedua yang diajukan bahwa tidak ada pengaruh yang signifikan antara dukungan sosial terhadap stress akademik sehingga hipotesis ditolak. Hasil penelitian ini memiliki kesamaan dengan beberapa penelitian yang sama sebelumnya bahwa ukungan sosial tidak memiliki pengaruh yang signifikan terhadap stress akademik.
Penelitian ini menguji satu persatu aspek dukungan sosial dari Cutrona yaitu attachment, social integration, reassurance of worth, reliabel alliance, guidance dan opportunity for nurturance tidak memiliki hubungan yang signifikan dengan stress akademik.

Dimensi dukungan sosial yang tidak signifikan dalam mengelola stres akademik terdiri dari attachment, social integration, guidance, dan opportunity for nurturance. Salah satu dimensi dukungan sosial yaitu attachment. Attachment adalah kelekatan emosional yang dalam penelitian ini tidak signifikan berpengaruh dalam mengelola stres akademik, karena saat ini siswa hanya menjalin kedekatan sehai-hari dengan orang tua dirumah, teman-teman sekelas merupakan orang baru yang belum begitu mempunyai hubungan dekat dengan siswa, begitu juga dengan guru disekolah sehingga siswa tidak terlalu memiliki kelekatan dengan orang lain disekitarnya. Kelekatan dan pertemanan juga tidak selalu membuat siswa mampu mengatasi stress yang dialami siswa, ini sejalan dengan penelitian yang dilakukan oleh Rose, Carlson dan Waller mengungkapkan dalam salah satu aspek dukungan sosial yaitu persahabatan dapat menguntungkan dan merugikan terkait dengan kecemasan dan stress [26].

Hasil penelitian ini juga didiukung oleh penelitian [27] yang menemukan bahwa tidak ada pengaruh dukungan sosial terhadap stress selama pembelajaran bagi mahasiswa. Dukungan sosial tidak berpengaruh terhadap stress diakibatkan karena dukungan yang didapatkan tidak sesuai dengan apa yang dibutuhkan oleh mahasiwa. Hal ini sejalan dengan penelitian terdahulu bahwa ada beberapa faktor yang berhubungan dengan penolakan dari sebuah dukungan, yaitu bantuan yang diberikan oleh orang lain tidak dianggap sebagai kebutuhan. Hal ini dapat terjadi kerena seseorang tidak menginginkan bantuan dari orang lain. Kesesuaian antara dukungan sosial dengan kebutuhan, menekankan pada pentingnya jenis dukungan sosial dengan kebutuhan individu [8].

Hasil penelitian di atas sejalan dengan beberapa aspek yang ada pada variabel yang diukur pada penelitian ini. Seperti social integartion, reassurance of worth, dan opportunity for nurturance. Aspek tersebut samasama mengukur dukungan sosial yang berorientasi secara emsosional terhadap siswa. Kenyataannya, saat ini siswa lebih membutuhkan dukungan langsung maupun instrumental dalam menunjang pembelajaran siswa selama belajar online dirumah seperti perangkat yang mendukung (smartphone, dan laptop), jaringan yang mendukung, dan paket data yang cukup selama pembelajaran berlangsung serta informasi yang jelas dan bermanfaat. Sehingga dapat dikatakan penelitian ini kurang menggali aspek dukungan instrumental secara langsung yang didapatkan siswa. Penelitian sebelumnya [28] mengatakan dukungan sosial mempunyai hubungan yang negatif dengan stress 
akademik dimana dukungan sosial mampu mengurangi tingkat stres akademik pada siswa. Aspek yang diukur lebih bervariasi yaitu aspek intrumental, emoisioal, ketersediaan bantuan dari orang lain dan aspek informational. Sehingga dukungan sosial yang diukur mampu mengurangi stres akademik pada siswa. Aspek selanjutnya guidance yaitu bimbingan. Berdasarkan wawancara peneliti dengan siswa, pada pembelajaran daring siswa terkadang merasa tidak selalu dibimbing dalam memahami pelajaran oleh guru. Guru mata pelajaran hanya memberikan video, menjelaskan secara singkat lalu memberikan tugas. Siswa terkadang tidak paham dengan apa yang harus dikerjakan.

Hipotesis minor ketiga pada penelitian ini adalah tidak terdapat pengaruh gaya belajar visual terhadap stres akademik pada siswa kelas VII SMP X Yogyakarta. Pada hipotesis kedua yang diajukan bahwa tidak ada pengaruh yang signifikan antara gaya belajar visual terhadap stress akademik sehingga hipotesis ditolak. Penelitian ini didukung oleh penelitian sebelumnya [10] yang menyatakan bahwa gaya belajar visual secara signifikan tidak dapat menurunkan stres akademik seseorang. Temuan penelitian ini adalah gaya belajar visual akan meningkatkan harga diri siswa dalam belajar sehingga menambah motivasi siswa dalam berprestasi. Penelitian ini juga menemukan bahwa siswa dengan gaya belajar visual adalah siswa dengan tingkat stres akademik yang tertinggi. Sehingga gaya belajar visual tidak dapat dijadikan pengaruh dalam menurunkan stres akademik siswa.

Hasil penelitian ini juga menunjukan bahwa siswa paling banyak menggunakan gaya belajar visual dengan kategorisasi sedang sebanyak 126, lalu rendah sebanyak 34 siswa dan kategorisasi tinggi paling sedikit yaitu 27 siswa. Dari hasil kategorisasi, peneliti berasumsi bahwa saat ini siswa yaqng paling banyak dengan kategorisasi sedang yang menggunakan gaya belajar visual baru mulai beradaptasi dengan gaya belajar visual dikarenakan situasi dan kondisi yang mengharuskan belajar secara visual. Sehingga karakteristik gaya belajar visual yang diukur seperti, belajar secara teratur, mampu memperhatikan segala sesutau, mudah mengingat dengan gambar serta mampu melihat sesuatu secara menyeluruh baru muncul dan belum signifikan mempengaruhi siswa dalam menurunkan stres belajar.

Setiap siswa memiliki gaya belajar yang berbeda sesuai dengan minat dan kebiasaan mereka, sehingga situasi pandemi covid pada penelitian ini tidak cukup berpengaruh terhadap penggunaan gaya belajar visual pada siswa. Gaya belajar yang berbeda pada setiap siswa juga tidak cukup dalam berpengaruh terhadap kemampuan siswa dalam menyikapi tuntutan akademik yang dimilikinya. Hal ini didukung oleh penelitian sebelumnya [29] yang berjudul "Kaitan antara Gaya Belajar, Kemandirian Belajar, dan
Kemampuan Pemecahan Masalah Siswa SMP dalam Pembelajaran Matematika". Hasil penelitian ini menunjukkan setiap siswa dengan gaya belajar apapun, mempunyai kecenderungan yang sama, baik dalam hal kemandirian belajarnya maupun dalam kemampuan pemecahan masalah matematis yang dimilikinya.

Hasil sumbangan efektif dari penelitian ini didapatkan variabel penyesuaian diri berkontribusi sebabnyak 64,9\% terhadap stres akademik siswa. Selebihnya stres akademik dipengaruhi oleh beberapa faktor lain yang tidak diteliti oleh peneliti seperti hardiness, self regulated learning dan phychological well being. Stress akademik dapat dipengaruhi oleh hardiness, yang berarti hardniness mampu menurunkan stress akademik mahasiswa teknik sipil di Universitas Diponegoro [30]. Self regulated learning secara signifikan juga mampu menurunkan stress akademik selama pembelajaran daring, berdasarkan hasil penlitian didapatkan hasil bahwa adanya pengaruh yang signifikan antara self regulated learning dengan stres akademik [31]. Selanjutnya, phychological well being juga memiliki pengaruh yang signiifkan dalam menurunkan stres akademik siswa. Siswa yang memiliki phychological well being yang tinggi tidak akan mudah mengalami stres akademik [32].

\section{Kesimpulan}

Berdasarkan hasil analisis data dan pembahasan, maka kesimpulan dari penelitian ini adalah terdapat pengaruh yang sangat signifikan antara penyesuaian diri, dukungan sosial dan gaya belajar visual terhadap stres akdemik siswa kelas VII dimasa pandemi. Variabel penyesuaian diri memiliki pengaruh yang sangat signifikan terhadap stres akademik yang berarti semakin tinggi kemampuan penyesuaian diri siswa maka akan semakin rendah tingkat stres akademik yang dialami, begitu pula sebaliknya. Variabel dukungan sosial dan gaya belajar visual tidak memiliki pengaruh terhadap stres akademik siswa dimasa pandemi.

\section{Daftar Rujukan}

[1] Rahmawati, W. K. (2017). Efektivitas teknik restrukturisasi kognitif untuk menangani stres akademik siswa. Jurnal

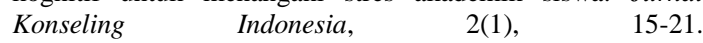
http://ejournal.unikama.ac.id/index.php/JKI/article/view/1636

[2] Mamnuah, S. R. (2021). Tingkat stres berhubungan dengan pencapaian tugas perkembangan pada remaja. Jurnal Ilmu Keperawatan Jiwa, 4(1), 107-116. https://journal.ppnijateng.org/index.php/jikj

[3] Purwiantomo, D., \& Rusmawati, D. (2020). Hubungan antara kecerdasan emosi dengan stress akademik pada siswa SMA Islam Al-Azhar 14 Semarang. Jurnal Empati, 9(6), 472-476. https://ejournal3.undip.ac.id/index.php/empati/article/view/30 $066 / 25051$

[4] Santrock, W. J. (2003). Adolescence. Alih bahasa: Adelar \& Saragih. Erlangga. 
[5] Barseli, M., Ifdil, I., \& Nikmarijal. (2017). Konsep stres akademik siswa. Jurnal Konseling dan Pendidikan, 5(3), 143148. https://doi.org/10.29210/119800

[6] Agustiningsih, N. (2019). Gambaran stres akademik dan strategi koping pada mahasiswa keperawatan. Jurnal Ners dan Kebidanan, 6(2), 241-250 https://Doi:10.26699/jnk.v6i2.ART.p241-250

[7] Heo, J., \& Han, S. (2017). Effects of motivation, academic stress and age in predicting self-directed learning readiness (SDLR): Focused on online college students. Education and Information Technologies, 23(1), 61-71. https://doi.org/10.1007/s10639-017-9585-2

[8] Sarafino, E.P., \& Smith, T.W. (2014). Health psychology : Biopsychosocial interaction seventh edition. Jhon Wiley \& Sons, Inc.

[9] Prashnig, B. (2007). The power of learning styles (penerjemah: fauziah, $n$.). Kaifa.

[10] Rahman, S. A., Ali, H. W., Rasool G., \& Siddique, I. (2021). Effect of learning atyles on self-esteem and stress levels of university students. Pakistan Journal of Medical and Health Sciences, $\quad$ 15(2), 469-472. https://www.researchgate.net/publication/350897286_Effect_ of_Learning_Styles_on_Self

[11] Yikealo, D., Yemane, B., \& Karvinen, I. (2018). The level of academic and environmental stress among college students: a case in the college of education. Open Journal of Social Sciences, $\quad 06(11)$, https://doi.org/10.4236/jss.2018.611004

[12] Olejnik, S. N., \& Holschuh, J. P. (2016). College rules! how to study, survive, and succeed in college ( $4^{\text {th }}$ edition). Ten Speed Press

[13] Bedewy, D., \& Gabriel, A. (2015). Examining perception of academic stress and its sources among university student : The perception of academic stress scale. Healt Psychology Open, 2(2), $1-9$. https://doi.org/10.1177\%2F2055102915596714

[14] Kartono, S. (2015). Patologi sosial. PT. Raja Grafindo Persada.

[15] Schneiders, A. A. (1955). Personal Adjustment and Mental Health. Holt, Rinehart And Winston.

[16] King, L. A. (2017). Psikologi umum. Salemba Humanika.

[17] Cutrona, C. E., \& Russell, D. W. (1987). The provisions of social relationships and adaptations to stress. Advances in Personal Relationships, 37-67. https://www.researchgate.net/profile/Daniel-Russell3/publication/271507385_The_Provisions_of_Social_Relatio nships_and_Adaptation_to_Stress/links/54c960b40cf $2807 \mathrm{dcc}$ 265ce2/The-Provisions-of-Social-Relationships-andAdaptation-to-Stress.pdf

[18] Karwati, E., \& Priansa, D. J. (2015). Manajemen kelas classroom management guru profesional yang inspiratif, kreatif, menyenangkan, dan berprestasi. Alfabeta.

[19] Bradway, L., \& Hill, B. A . (2003). Pola-pola belajar: Kiatkiat cerdas mencerdaskan anak, terjemahan M.Khoirul Anam. Inisiasi Press.

[20] DePorter, B., \& Hemacki, M. (2011). Terjemahan alwiyah abdurrahman, quantum learning nyaman dan menyenangkan. Kaifa.
[21] Sari, M. K. (2020). Tingkat stres mahasiswa S1 keperawatan tingkat satu dalam menghadapi wabah covid 19 dan perkuliahan daring di stikes karya husada kediri. Jurnal Ilmiah Pamenang, 2(1), 31-35. https://doi.org/10.51214/bocp.v2i2.44

[22] Suwinyatichaiporn, T., \& Johnson, Z. D. (2020). The impact of family and friends social support on Latino/a firstgeneration colllege students' perceived stress, depression, and social isolation. Journal of Hispanic Higher Education, 1-18. https://doi.org/10.1177/1538192720964922

[23] Busari, A. O. (2017). The Relationship between personality types, learning styles, motivation, self esteem and stress among distances learners in ibadan study center. International Journal of Innovation and Applied Studies, 19(4), 850-862. http://www.ijias.issr-journals.org/

[24] Saniskoro, B., \& Akmal, S. (2017). Peranan penyesuaian diri di perguruan tinggi terdahap stress akadmeik pada mahasiwa perantau di jakarta. Jurnal Psikologi Ulayat, 4(1), 95-106. https://doi.org/10.24854/jpu67

[25] Maulina, B., \& Sari, D. R. (2018). Derajat stres mahasiswa baru fakultas kedokteran ditinjau dari tingkat penyesuaian diri terhadap tuntutan akademik. Jurnal Psikologi Pendidikan dan Konseling, 4(1), 1-5. DOI:10.26858/jpkk.v4i1.4753

[26] Santrock, J. W. (2011). Child Development (Perkembangan Anak Edisi 11 Jilid 2, Penerjemah: Rachmawati dan Kuswanti). Erlangga.

[27] Dawi, M. M., \& Nisa, W. I. (2021). Pengaruh Dukungan Sosial terhadap tingkat Stres dalam Penyusunan Tugas Akhir Skripsi. Psikodinamika - Jurnal Literasi Psikologi, 1(1), 6775. https://doi.org/10.36636/psikodinamika.v1i1.556

[28] Salmon, AG. \& santi, DE. (2021). Dukungan sosial dengan stres akademik mahasiswa perantau dalam pembelajaran daring di masa pandemi covid-19. Buku Abstrak Seminar Nasional "Memperkuat Kontribusi Kesehatan Mental dalam Penyelesaian Pandemi Covid 19: Tinjauan Multidisipliner", 128-135.

[29] Sundayana, R. (2016). Kaitan antara gaya belajar, kemandirian belajar, dan kemampuan pemecahan masalah siswa SMP dalam pembelajaran matematik. Jurnal

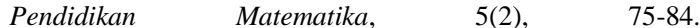
https://doi.org/10.31980/mosharafa.v5i2.262

[30] Risana, I. W., \& Kustanti, E. R. (2020). Hubungan antara hardiness dengan stres akademik pada mahasiswa departemen teknik sipil universitas diponegoro. Jurnal EMPATI, 9(5), 370-374.

https://ejournal3.undip.ac.id/index.php/empati/article/view/29 255

[31] Mubarok, A. \& Harmaleni, T. (2021). Kontribusi selfregulated learning terhadap stres akademik mahasiswa selama menjalani perkuliahan daring. Jurnal Riset Psikologi, 2021(3), 1-11. http://dx.doi.org/10.24036/jrp.v2021i3.11979

[32] Oktaviani, AZ. \& Suprapti, Veronika. (2021). Pengaruh psychological well-being terhadap stres akademik siswa SMA di masa covid-19. Buletin Riset Psikologi dan Kesehatan Mental, 1(1), 965-975. http://dx.doi.org/10.20473/brpkm.v1i1.27667 